\title{
Grazing effects on woody and herbaceous plant biodiversity on a limestone mountain in northern Tunisia
}

\author{
David Anthony Kirk ${ }^{\text {Corresp., } 1}$, Katherine Hébert ${ }^{2}$, Frank Barrie Goldsmith ${ }^{3}$ \\ ${ }^{1}$ Aquila Conservation \& Environment Consulting, Ottawa, Ontario, Canada \\ 2 Département de biologie, Faculté des Sciences, Université de Sherbrooke, Sherbrooke, Québec, Canada \\ 3 Department of Geography, University College London, University of London, London, United Kingdom \\ Corresponding Author: David Anthony Kirk \\ Email address: david@aquilaecology.com
}

Mediterranean maquis vegetation is highly biodiverse, but widespread grazing poses a challenge for management and conservation. We sampled woody and herbaceous plants separately on a limestone mountain with strong mesic-xeric gradients in Tunisia's Parc National de L' Ichkeul, assessed grazing pressure (on a scale of 1-3), and asked whether grazing had a significant effect on plant compositional abundance before and after controlling for environmental covariates. Sites on the more mesic lakeside face of the mountain were most compositionally unique, and forbs contributed most to the herbaceous beta-diversity on the mountain. We used variance partitioning to separate the collective and individual effects of the abiotic environment, grazing, human activity, and space on herbaceous and woody beta-diversity. However, the individual effect of grazing on overall plant community composition was confounded with space, due to the spatially autocorrelated grazing pressure on the mountain. Importantly, we found that herbaceous and woody communities responded differently to increasing levels of grazing intensity: herbaceous beta-diversity was highest between sites with no grazing pressure, while woody beta-diversity peaked under light grazing. Herbaceous community composition was sensitive to any intensity of grazing pressure, and biotic homogenization occured under moderate-to-high grazing pressure. On the other hand, woody community composition remained relatively similar under no to light grazing pressure, but differed under moderate-to-heavy grazing. Using a one-way permutational analysis of variance analysis, we showed that grazing had a significant effect when controlling for abiotic and spatial covariates. Our findings offer insight into the effects of grazing on maquis vegetation at Jebel Ichkeul, acting as a microcosm of similar conservation and management issues elsewhere in the Mediterranean. We suggest that a combination of monitoring and carefully controlled grazing may enhance plant diversity and maintain the region's biodiverse maquis vegetation, potentially maintaining a key climate refugium for 
vulnerable endemic species. Importantly, our study provides a useful baseline of the plant assemblages at Jebel Ichkeul with which to compare future vegetation changes. 
1

2

3

4

5

6

7

8

9

10

11

12

13

14 Canada

15

16

${ }^{2}$ Current address: Aquila Conservation \& Environment Consulting, Ottawa, Ontario, Canada

17

18 Send correspondence to: Dr. D. A. Kirk, Email: david@aquilaecology.com; telephone: (613) 290

$19 \quad 7472$

20

21

22

Abstract. Mediterranean maquis vegetation is highly biodiverse, but widespread grazing poses a challenge for management and conservation. We sampled woody and herbaceous plants 
23 separately on a limestone mountain with strong mesic-xeric gradients in Tunisia's Parc National de

24 L' Ichkeul, assessed grazing pressure (on a scale of 1-3), and asked whether grazing had a 25 significant effect on plant compositional abundance before and after controlling for environmental

26 covariates. Sites on the more mesic lakeside face of the mountain were most compositionally

27 unique, and forbs contributed most to the herbaceous beta-diversity on the mountain. We used

28 variance partitioning to separate the collective and individual effects of the abiotic environment,

29 grazing, human activity, and space on herbaceous and woody beta-diversity. However, the

30 individual effect of grazing on overall plant community composition was confounded with space,

31 due to the spatially autocorrelated grazing pressure on the mountain. Importantly, we found that

32 herbaceous and woody communities responded differently to increasing levels of grazing

33 intensity: herbaceous beta-diversity was highest between sites with no grazing pressure, while

34 woody beta-diversity peaked under light grazing. Herbaceous community composition was

35 sensitive to any intensity of grazing pressure, and biotic homogenization occured under moderate-

36 to-high grazing pressure. On the other hand, woody community composition remained relatively

37 similar under no to light grazing pressure, but differed under moderate-to-heavy grazing. Using a

38 one-way permutational analysis of variance analysis, we showed that grazing had a significant

39 effect when controlling for abiotic and spatial covariates. Our findings offer insights into the effects

40 of grazing on maquis vegetation at Jebel Ichkeul, acting as a microcosm of similar conservation and

41 management issues elsewhere in the Mediterranean. We suggest that a combination of

42 monitoring and carefully controlled grazing may enhance plant diversity and maintain the region's

43 biodiverse maquis vegetation, potentially maintaining a key climate refugium for vulnerable 
44 endemic species. Importantly, our study provides a useful baseline of the plant assemblages at 45 Jebel Ichkeul with which to compare future vegetation changes. 
Introduction

49 Humans and their livestock have influenced Mediterranean shrublands for millennia (Naveh,

50 1990). This long history of widespread human activity has played an integral and pervasive role in

51 shaping the region's disturbed, yet remarkably biodiverse landscape (Mazzoleni et al. 2004;

52 Papanastasis, 1998; Rundel, 1998; Vogiatzakis et al. 2006; Blondel et al. 2010). Evaluating the

53 impacts of humans' coevolution with the Mediterranean shrublands is thus an ongoing challenge

54 for the management and conservation of this region's biodiversity (Falcucci, Maiorano, \& Boitani, 55 2007; Rundel et al., 2016).

Historically, low intensity grazing by domestic livestock and fires set by shepherds

maintained the floristically rich and heterogeneous landscapes of the Mediterranean maquis,

which were previously shaped by more abundant native herbivores (Le Houérou, 1981;

Papanastasis, 1998; Papanastasis, Kyriakakis, \& Kazakis, 2002). The resulting shrubland communities are of high ecological value, due to their rich diversity of annuals, and geophytes

61 from the Orchidaceae, Iridaceae, and Liliaceae (Pons, 1981; Quézel, 1981). Under certain conditions, grazing can also effectively restore plant diversity after shrub encroachment in dry grasslands (Elias and Tischew 2016; Elias et al. 2018; see also Török et al. 2016) and in heathlands

64 (Rupprecht, Gilhaus \& Hölzel, 2016). Without such disturbance, many shrublands develop into

65 forests, leading to a loss of plant diversity and a build-up of organic matter, rendering them 66 susceptible to wildfires (Rackham \& Moody 1996; Perevolotsky and Seligman 1998; Henkin 2011). 67 Although grazing can maintain endemic species and regulate ecosystems (Gomez-Campo, 1985), overgrazing and uncontrolled wood-cutting can also reduce plant diversity, and cause erosion or 
70 of different intensities of grazing disturbance on biodiversity is therefore fundamental to inform

71 management strategies in maquis ecosystems.

72 The effects of grazing on plant biodiversity are equivocal, being subject to various

73 temporal, spatial, and ecological contingencies (Olff \& Ritchie, 1998; Olsvig-Whittaker et al., 2006).

74 On islands, intensive overgrazing by goats has devastated vegetation and threatened the 75 persistence of many island endemics (Campbell \& Donlan, 2005). However, many Mediterranean

76 plant species have coevolved with herbivores and developed strategies to resist grazing, including

77 spininess, chemical repulsion, prostrate growth, and an ability to grow on remote rocky cliffs that

78 are inaccessible to livestock (Papanastasis, 1998). Grazing has therefore applied a continuous

79 selective pressure on plant species over extensive time scales, likely influencing plant community

80 composition and diversity across the entire region (Rundel et al., 2016).

Characterized by extremely high floristic richness, the Mediterranean region holds about $10 \%$ of global plant species diversity $(25,000$ species $)$ on only $2 \%$ of the world's terrestrial surface area, and half of these plant species are endemic to the region (Médail and Quézel, 1997; Radford et al. 2011). The stability of climate across timescales, including provision of Pleistocene refugia, is thought to have prevented species' extinctions and facilitated speciation, leading to this remarkably high biodiversity in the Mediterranean Basin (Nogués-Bravo et al. 2008; Nogués-Bravo et al. 2012). The resulting characteristic shrub formations are occur only in five areas: California 88 (United States), Chile, South Africa, Australia and the Mediterranean Basin in southern Europe and North Africa (Cowling et al. 1996; Tomaselli 1977; Di Castri 1981). 
92 conservation dilemma (Blondel et al. 2010). Primary "natural" vegetation remains in only $4.7 \%$ of

93 the Mediterranean basin (Geri, Amici \& Rocchini, 2010), and many of these remaining wildlands

94 are restricted to mountainous or coastal regions with steep slopes that preclude cultivation.

95 Some protected areas were implemented to conserve Mediterranean shrublands, but do not

96 cover enough land to effectively buffer them against the erosion of vegetation diversity (Wilson et

97 al., 2007). With forecasted increases in the frequency and magnitude of droughts and

98 desertification due to climate change, areas of high plant endemism in the Mediterranean will

99 likely lose their biodiversity and functional heterogeneity (Gauquelin et al. 2016; de la Riva et al.

100 2016). Thus, the challenge of integrating multiple uses of Mediterranean landscapes to effectively

101 protect the region's remarkable diversity is fundamental to the conservation of Mediterranean

102 flora.

103 Jebel Ichkeul, a limestone mountain within Le Parc National de L'Ichkeul in the north of the

104 Republic of Tunisia, represents a microcosm of the conservation issues faced by Mediterranean

105 vegetation, including grazing. In a recent assessment of the threats to Important Plant Areas (IPAs)

106 in the southern and eastern Mediterranean, Radford et al. (2011) identified overgrazing as the

107 main threat to IPAs in Tunisia (see also Underwood et al. 2009). Assessing the influence of grazing

108 pressure and human activity on plant community composition in Jebel Ichkeul can therefore

109 provide insight into how these threats might be affecting other Mediterranean shrublands, and to

110 inform their protection and management.

111 In this paper, we investigate the influence of grazing pressure on woody and herbaceous

112 plant communities on Jebel Ichkeul, a limestone mountain with strong mesic-xeric gradients. More

113 specifically, we ask: 1) how grazing, the abiotic environment, and space collectively and separately 
114 shape herbaceous and woody plant community composition on Jebel Ichkeul, with a special focus

115 on the influence of grazing; 2) how the intensity of human activity (using Olea europaea size and

116 density as a proxy) influences plant community composition on Jebel Ichkeul, in concert with and

117 independently of these ecological drivers; and 3) how different grazing intensity levels influence

118 plant beta-diversity on Jebel Ichkeul, and which plant taxonomic and functional groups are

119 associated with each level.

120 We predicted that grazing, as well as the abiotic environment and spatial relationships

121 between sites, would collectively and individually explain variation in plant community

122 composition across sites (Osem, Perevolotsky \& Kigel, 2007). Second, we expected that human

123 activities like woodcutting would apply a selective pressure on community composition, explaining

124 additional plant beta-diversity across sites (Agra \& Ne'eman, 2009). Third, we predicted that

125 grazing intensity should influence beta-diversity, where beta-diversity should be highest under

126 light browsing, and should be lowest under both grazing extremes (i.e. unbrowsed and moderate-

127 to-heavily intensity; Lázaro et al. 2016). 


\section{Methods}

130

\section{Study area}

132 Set in the Mateur plain, Jebel Ichkeul is $25 \mathrm{~km}$ southwest of Bizerte in northeastern Tunisia and 15

$133 \mathrm{~km}$ south of the Mediterranean Sea ( $37^{\circ} 10^{\prime} \mathrm{N}, 09^{\circ} 40^{\prime} \mathrm{E}$; Figure 1). It is surrounded along its

134 northern flanks by Garaet el Ichkeul, an internationally important wetland; both the Jebel and lake

135 are included within the National Park and World Heritage Site (IUCN 2003). South of the southern

136 perimeter of the Jebel, there is intensive arable farming, pasture and orchards (UNEP/WCMC,

137 2003). Formerly an island within Lac Ichkeul, the dolomitic massif covers an area of 1,363 ha (13.6

$138 \mathrm{~km}^{2}$ ); 690 ha of this was gazetted in the original declaration of the National Park in 1977 (Hollis,

139 1977, 1986). Jebel Ichkeul was listed as an Important Plant Area (IPA) in 2000 (Radford, Catullo \&

140 de Montmollin, 2011), and is nationally important (Peterken and Radford, 1971). Of the 29 plant

141 families known to occur in the Mediterranean region (Quézel, 1981), 24 occur on the Jebel,

142 including the rare Tunisian endemic Teucrium schoenenbergeri (Fay, 1980).

143 Jebel Ichkeul was listed in the European Red list of Habitats as one of the most typical

144 examples of Olea europaea var sylvestris with Ceratonia siliqua and Pistacia lentiscus along with

145 southern Andalusia, Menorca, Sardinia, Sicily, Calabria and Crete (European Environment Agency,

146 2017). At the time of our study, the Jebel's forests and maquis provided grazing for livestock,

147 especially in autumn and winter (Hollis, 1977). At other times of year, the wetlands and marshes of

148 the National Park were a source of forage for over 2,500+ livestock (Anon, 1988). Combined with

149 uncontrolled woodcutting for firewood on the southern slopes, grazing pressure caused loss of

150 vegetation cover and reduced species diversity, leading to increased soil erosion and the spread of

151 invasive plants (Fay, 1980). 
153 (dolomite, calc-schist and marble), dissected relief, high altitude (maximum 512 m.a.s.l.), the

154 adjacent Lac Ichkeul, and spatially-variable anthropogenic activity (Daoud-Bouattour et al. 2007).

155 The northern slopes facing Lac Ichkeul are generally mesic with relatively continuous vegetation

156 cover. By contrast, the southern slopes of the mountain feature xeric plant communities, often in

157 various states of degradation. These effects were most apparent close to gourbi village

158 settlements and the Hammams (hot springs) located at the foot of the mountain. Illegal quarries,

159 since closed, also mined limestone on the southern slopes of the Jebel, and contributed to the

160 xeric conditions at these sites, and potentially dust pollution (Kirk, 1983). A road running along the

161 southern flanks of the mountain links the villages and quarries and is served by some secondary

162 roads from the Mateur Plain (Figure 1). On the southern slopes of the mountain, calc-schist parent

163 material results in sites with high soil $\mathrm{pH}$, while the northern slopes are mostly dolomitic. Jebel

164 Ichkeul occurs in the Mediterranean bioclimatic zone with a summer drought (Daget, 1977). Mean

165 monthly temperatures range from $11.3^{\circ} \mathrm{C}$ in January (winter minimum $0^{\circ} \mathrm{C}$ ) to a mean of $25.2^{\circ} \mathrm{C}$

166 in July (summer maximum $40^{\circ} \mathrm{C}$ ). The average annual rainfall is $625 \mathrm{~mm}$, with only 4 per cent of

167 this falling in summer (Hollis, 1977).

168

169 
Plant community surveys and sampling design

171 The first author conducted all sampling between 18 June and 7 August 1983. To describe plant

172 species distribution and abundance, we located 78 quadrats on the Jebel, stratified using the data

173 and vegetation maps in Fay (1980) for guidance. Except for inaccessible crags and steep cliffs, we

174 sampled all vegetated areas. Although the general areas of survey sites were not chosen

175 randomly, they were widely dispersed and spaced over the Jebel and sampled all community types

176 in Fay (1980). At each site, we threw a quadrat randomly to locate the central stake. We used a

177 nested quadrat design with dimensions of $2 \times 2 \mathrm{~m}, 5 \times 5 \mathrm{~m}, 7.07 \times 7.07 \mathrm{~m}, 10 \times 10 \mathrm{~m}$, and $14 \times 14 \mathrm{~m}$

178 (Bunce, 1982). We estimated cover-abundance for herbaceous and woody species within the $2 \mathrm{x}$

$1792 \mathrm{~m}$ quadrat and the $10 \times 10 \mathrm{~m}$ quadrat, respectively, using a modified Braun Blanquet scale (e.g.,

$180<1 \%, 1-5 \%, 6-10 \%, 11-25 \%, 26-50 \%, 51-75 \%,>75 \%)$. In the remaining quadrats, we recorded

181 presence-absence of species, but here present only data from the $2 \times 2 \mathrm{~m}$ and $10 \times 10 \mathrm{~m}$ quadrats.

182 On average, three sites (nested quadrats) were surveyed during 8-10 hours per day.

183

Identifying plant species and development of functional groups

185 Plant names and occurrences in the national park were verified by a plant ecologist (A. Daoud

186 Bouattour, University of Tunis, pers. comm. 2012), and final taxonomy is based on a catalogue of 187 plants of Tunisia (Le Floc'h et al. 2010), as well as a flora of the national park compiled since our 188 study (Daoud-Bouattour et al. 2007).

189 Because we surveyed woody and herbaceous species' abundance at different spatial 190 scales, we considered herbaceous and woody plant communities separately in all analyses. We

191 further classified species into taxonomic and functional groups predicted to respond differently to 
192 grazing intensity: Poaceae (Graminoids), Legumes, Geophytes, Forbs (annual and perennial), shrub

193 legumes and shrubs/trees (similar to those in Fernández-Lugo et al. 2013). The "Forbs" functional

194 group contains ferns, cactuses, club mosses and some unidentified mosses. We did not

195 differentiate between annual and perennial species as in Fernández-Lugo et al. (2013), because

196 our study took place over a single season.

197

198

\section{Assessing grazing intensity}

199 At each of the quadrat locations within the $10 \times 10 \mathrm{~m}$ square, we ranked browsing by livestock on

200 the principal woody plant species. We recognized that the effect of grazing could vary between

201 woody and herbaceous species, that certain species might be preferred, and that these

202 preferences may differ by livestock type (Tóth et al., 2018). However, we were unable to quantify

203 grazing on herbaceous species, and therefore assume that browsing on woody plants (probably

204 almost entirely by goats) was indicative of overall grazing intensity on both woody and herbaceous

205 species.

206 We categorized grazing intensity into three levels: 1) unbrowsed (i.e. dense forests, forests

207 with gaps or high altitude arborescent matorral), 2) lightly browsed (i.e. dense middle or low

208 matorral with trees showing signs of browsing on shrubs), and 3) moderate to heavy browsing (i.e.

209 bushes clipped to a hedge-like shape or severely clipped to short stunted bushes), following

210 Tomaselli (1977). We also recorded the activity of herbivorous mammals qualitatively by signs

211 such as hair on tree trunks, droppings, and feeding signs (e.g. wild boars Sus scrofa) often left

212 uprooted tubers and soil disturbance)) but these were not quantified. Of the 78 sampled sites,

$21371 \%(n=55)$ were classified as unbrowsed (level 1$), 12.8 \%(n=10)$ as lightly browsed (level 2$)$, and

$21416.7 \%(n=13)$ as moderately to heavily browsed (level 3). Heavily grazed sites (level 3) were 
215 generally of low altitude with more rock outcropping and smaller-diameter olive trees. See Figure

2162 for an assessment of percent occurrence and relative abundance of woody species in each

217 grazing class.

218

219

Measuring abiotic environmental variables

220 To disentangle the effect of grazing from environmental covariates on plant species compositional

221 turnover (Arévalo et al., 2011), we measured several abiotic variables at the centre of each

222 quadrat (Table 1; see below). We recorded altitude with a barometric field altimeter. Because

223 slope aspect plays an important role in the distribution of woody vegetation in the Mediterranean

224 (Sternberg \& Shoshany, 2001), we also measured slope using an inclinometer (Abney Level -

225 Eugene Dietzgen, Chicago, USA) and recorded compass aspect as a proxy for solar insolation.

226 Parent material characteristics play a strong role in shaping Mediterranean shrub communities

227 (Molina-Venegas et al., 2016), so we recorded the percentage of rock outcropping or rock cover at 228 quadrats.

230 Olea europaea as a proxy for anthropogenic activity

231 Woody vegetation shades other plant species, and thus modulates the composition and

232 abundance of herbaceous plant species (Agra \& Ne'eman, 2009; Segoli et al., 2012). Woody

233 vegetation, especially Olea europaea, is also a key indicator and surrogate for the intensity of

234 anthropogenic activities, including assessment of grazing and woodcutting activities. Therefore, we

235 measured Olea europaea stems (> 4cm) in the $10 \times 10 \mathrm{~m}$ quadrat at breast height (dbh; c $1.5 \mathrm{~m})$

236 and at $30 \mathrm{~cm}$ above ground level for 69 sites (data were not available for 9 sites). We present

237 results using stem size at $30 \mathrm{~cm}$ height, because most trees were too small to obtain a breast 
238 height measurement in shallow soils or heavily grazed sites. We then calculated Olea densities in

$2390-5,6-10,11-15,16-20$ and $>20 \mathrm{~cm}$ circumference size classes. Where trees bifurcated, all stems

240 were measured and a calculation used to provide a single diameter comparable with a tree of the

241 same surface area (Supplementary Methods).

242

243 Spatial autocorrelation between sites

244 To assess positive spatial autocorrelation in plant community composition across the mountain,

245 we computed the local Moran's I for each site based on Hellinger distances, and tested for

246 significance using 999 random permutations. We also made the assumption that certain

247 unmeasured environmental covariates were spatially autocorrelated. For example, prevailing

248 westerly winds carry moisture from the lake and may create a humidity gradient from northerly

249 mesic vegetation to xeric southern vegetation at Jebel Ichkeul (Fay, 1980). Explicitly incorporating

250 spatial relationships between sites can help account for this spatial gradient in humidity and soil

251 moisture, which can have a strong influence on Mediterranean maquis vegetation (Sardans \&

252 Peñuelas, 2013). To account for the positive spatial autocorrelation between sites in subsequent

253 analyses, we computed positive distance-based Moran's eigenvector maps (dbMEMs; (Dray et

254 al. 2006; Legendre and Legendre 2012; Legendre and Gauthier 2014) based on site coordinates

255 determined from Google Earth. Local Moran's I and the positive dbMEMs were calculated using

256 the R package adespatial (Dray et al. 2018).

257

258 STATISTICAL ANALYSIS

259 Beta-diversity of herbaceous and woody communities 
260 We assessed the compositional differences between sites in herbaceous and woody

261 communities as the Hellinger distances between sites for each community type (Anderson et

262 al., 2011). To determine which sites harboured more ecologically unique communities, we

263 quantified each site's local contribution to beta-diversity (LCBD) for each community type

264 (Legendre \& De Cáceres, 2013). To identify the plant groups that most strongly drive beta-

265 diversity between sites, we also assessed each species' contribution to beta-diversity (SCBD),

266 summed for each functional group (Poaceae, legumes, forbs, geophytes; Legendre and De

267 Cáceres 2013). We tested the significance of LCBD values using permutation tests with 999

268 iterations.

269

270 Disentangling the ecological and anthropogenic drivers of plant beta-diversity

271 We first determined the combined and separate influences of ecological drivers on plant

272 community structure. We used distance-based redundancy analyses ( $d b-\mathrm{RDA})$ to quantify the

273 combined influence of the abiotic environment (altitude, slope, aspect, and rock-crop cover),

274 grazing intensity, and spatial autocorrelation (dbMEMs) on the Hellinger dissimilarities between

275 sites in the herbaceous and the woody plant communities. Model significance tests were based

276 on 999 permutations. We then used variation partitioning to disentangle the individual

277 influences of the abiotic environment, grazing, and spatial autocorrelation on the herbaceous

278 and woody plant beta-diversity (Borcard, Legendre \& Drapeau, 1992; Peres-Neto et al., 2006).

279 For the two plant community types, we partitioned Hellinger dissimilarities into fractions of

280 variation explained by [a] abiotic environmental variables (altitude, slope, aspect, and rock 
281 outcrop cover), [b] grazing classes, [c] spatial autocorrelation (dbMEMs). We then tested the

282 significance of each individual fraction using permutation tests with 999 iterations.

283 To determine the influence of anthropogenic activity on plant community composition,

284 we repeated the $\mathrm{db}$-RDA and variation partitioning analyses including only sites with Olea

285 europaea sizes and densities. For the two plant community types, we therefore partitioned

286 Hellinger dissimilarities into fractions of variation explained by [a] abiotic environmental

287 variables (altitude, slope, aspect, and rock outcrop cover), [b] grazing classes, [c] human activity

288 (Olea europaea sizes and densities), and [d] spatial autocorrelation (db-MEMs).

289 All db-RDA and variation partitioning analyses were conducted using the R package

290 vegan (Oksanen 2013).

291

292

Influence of grazing intensity on plant beta-diversity

293 To determine how grazing intensity influences plant beta-diversity, we tested for significant

294 differences in the variance of Hellinger dissimilarities between the three levels of grazing

295 intensity. We computed a test of the multivariate homogeneity of groups dispersions between

296 grazing classes and assessed significance of between-group differences using 999 permutations

297 (Anderson, 2006). Smaller multivariate site distances to the grazing-specific centroids are

298 interpreted as biotic homogenization, whereas larger distances are interpreted as biotic

299 differentiation. The multivariate homogeneity of group dispersions test was performed using

300 the R package vegan (Oksanen 2013).

301

To further tease out the influence of grazing intensity from the effects of abiotic, spatial,

302 and anthropogenic covariates, we performed one-way permutational multivariate analysis of 
303 variance (PERMANOVA) models with grazing as a factor and controlling for covariates. We

304 selected abiotic and spatial variables through sequential $\mathrm{AIC}_{\mathrm{c}}$ comparison of $\mathrm{db}-\mathrm{RDA}$ models.

305 We first compared db-RDA models including all abiotic covariates and grazing, and retained

306 abiotic variables from the best model. We repeated this with spatial variables (dbMEMs). A

307 PERMANOVA was then conducted to evaluate grazing intensity's effects on beta-diversity, with

308 the retained abiotic and spatial variables as covariates. Because grazing intensity is spatially

309 structured, we forced the order of entry in the PERMANOVA by entering grazing intensity first

310 in one set of models, and then entering it last in a second set of models. PERMANOVAs were

311 conducted first for all 78 sites, then separately for the subset of 69 sites for which

312 anthropogenic variables (i.e. Olea europea densities by size class) were available. We assessed

313 explanatory power using Type I sums of squares in the PERMANOVAs. We performed the db-

314 RDAs (best model subsets) and permutational multivariate analysis of variance using

315 PERMANOVA + (Anderson, Gorley \& Clarke, 2008).

316

317 


\section{Results}

319 Spatial autocorrelation between sites

320 Moran's I tests demonstrated positive spatial autocorrelation in plant community composition

321 within grazing classes, particularly in the woody communities (Supplementary Figure 1).

322 Herbaceous community composition showed significant positive spatial autocorrelation in 21 of $32355(38.2 \%)$ of unbrowsed sites, 5 of $10(50 \%)$ of lightly-browsed sites, and 11 of $13(84.6 \%)$ of

324 moderately-to-heavily browsed sites. Most strikingly, the sites with the highest positive spatial 325 autocorrelation for herbaceous species were on the southern, heavily grazed slopes of the Jebel

326 (Supplementary Figure 1). Woody community composition showed high levels of positive spatial

327 autocorrelation across all grazing classes: 47 out of 55 (85.5\%) in unbrowsed sites, 9 out of 10 328 sites (90\%) in lightly-browsed sites, and 11 out of 13 (84.6\%) in moderately-to-heavily browsed 329 sites. The influence of grazing and of other ecological and anthropogenic processes therefore

330 needed to be disentangled from the pervasive effect of spatial autocorrelation between sites in 331 both community types.

332

333 Beta-diversity of herbaceous and woody communities

334 Sites with the highest local contribution to beta-diversity (LCBD) (i.e. more compositionally 335 unique sites) were generally located on the lakeside face of the mountain, contributing up to $3362.04 \%$ (site 44 ) of total herbaceous beta-diversity, and up to $2.47 \%$ (site 51 ) of the overall woody

337 beta-diversity on the Jebel (Supplementary Figure 2). LCBD also differed significantly among 338 grazing classes for herbaceous plant species $\left(F_{2}=4.31, d f=2, P=0.02\right)$, but not for woody species $339\left(F_{2}=0.35, d f=2, P=0.7 ;\right.$ Figure 3$)$. 
Forbs contributed most to herbaceous beta-diversity (SCBD), followed by Poaceae,

341 Legumes, and Geophytes (Figure 4). Woody beta-diversity was largely attributed to woody

342 species other than legumes (Figure 4). Legumes almost exclusively contributed to beta-diversity in

343 unbrowsed and lightly browsed sites. It is also notable that of the 35 woody species, only 12

344 occurred in heavily grazed sites (Figure 2).

345

346 Disentangling the ecological and anthropogenic drivers of plant beta-diversity

347 The importance of ecological drivers on plant beta-diversity differed between herbaceous and

348 woody communities. In herbaceous communities, the db-RDA showed the abiotic environment,

349 grazing intensity, and spatial variables collectively explained relatively little $\left(R_{a d j}=0.047, p=\right.$

$350 \quad 0.001$ ) of the variation in beta-diversity between the 78 sites. Variation partitioning indicated that

351 abiotic variables ([a]) significantly explained a small portion of this variation $\left(R_{a d j}=0.015, p=\right.$

$3520.007)$, while grazing intensity ([b]) and spatial variables ([c]) showed no significant effects (Figure

353 5a). The individual effect of grazing intensity ([b]) could not be partitioned from the effects of

354 abiotic and spatial variables $\left(R_{a d j}=-0.003, p=0.8\right)$. Here, a negative $R_{a d j}$ indicated that grazing

355 intensity only explained the variation in beta-diversity when considered with the abiotic and

356 spatial covariates (Legendre and Legendre 2012). This suggests that grazing intensity is highly

357 correlated with the abiotic and spatial variables, making it difficult to isolate its influence on

358 herbaceous community composition.

359 In the woody community (Figure $5 b)$, the db-RDA demonstrated that $12.5 \%\left(R_{a d j}=0.125, p\right.$

$360=0.001)$ of the variation in beta-diversity within the woody community could be attributed to the

361 combined effect of the abiotic environment, grazing intensity, and spatial variables. As in the 
362 herbaceous community, the individual effect of grazing intensity ([b]) could not be partitioned

363 from the effects of the abiotic environment and spatial variables $\left(R_{a d j}=-0.005, p=0.9\right)$. Space

364 alone ([c]) significantly explained the greatest portion of the variation in beta-diversity across

365 woody sites $\left(R_{a d j}=0.044, p=0.001\right)$, while the individual effect of the abiotic environment ([a])

366 did not significantly explain plant beta-diversity after partitioning $\left(R_{a d j}=0.011, p=0.11\right)$.

To investigate the influence of anthropogenic activity on plant beta-diversity, we repeated

368

369

370

371

372

374

375

376

377

378

379

380

381

382

383 these analyses on 69 sites with the inclusion of Olea europea densities, as a proxy for human activities such as woodcutting. Including Olea density covariates slightly increased the explanatory power of both db-RDA models: the combined effect of the abiotic environment, grazing intensity, Olea densities, and spatial variables explained $7.6 \%\left(R_{\text {adj }}=0.076, p=0.001\right)$ of herbaceous beta-diversity, and $16.4 \%\left(R_{a d j}=0.164, p=0.001\right)$ of woody beta-diversity.

Variation partitioning further discerned the individual effects of the ecological and anthropogenic covariates. In the herbaceous community, space alone ([d]) still explained most variation $\left(R_{a d j}=0.019, p=0.03\right)$, followed closely by the abiotic environment $([a])\left(R_{a d j}=0.021, p=\right.$ 0.03) (Figure 5c). The individual effects of grazing intensity ([b]) and Olea densities ([c]) were both unable to significantly explain variation in herbaceous beta-diversity ([b]: $R_{a d j}=0.001, p=0.4 ;[\mathrm{c}]$ : $\left.R_{a d j}=0.012, p=0.09\right)$, although the effect of Olea densities was significant when considered with all other covariates $\left(R_{a d j}=0.015, p=0.01\right)$. Importantly, in the woody community, the individual effects of grazing intensity ([b]) and Olea densities ([c]) were successfully partitioned from the effects of spatial variables and the abiotic environment, respectively explaining $2.2 \%(p=0.001)$ and $2.1 \%(p=0.03)$ of woody beta-diversity (Figure $5 d)$. However, spatial variables still explained the largest fraction of woody beta-diversity $\left(R_{a d j}=0.024, p=0.01\right)$. 
386 The test for the homogeneity of multivariate dispersions indicated that beta-diversity differed

387 significantly among grazing classes in the herbaceous communities $(p<0.001)$, and was

388 marginally significantly different among grazing classes in the woody communities $(p=0.065$;

389 Figure 6). Herbaceous communities were more differentiated among unbrowsed sites, and

390 most homogenized in moderately-to-heavily grazed sites (Figure 6). Although the pattern was

391 less pronounced in the woody community, moderately-to-heavily grazed sites showed more

392 homogenization than sites with less grazing pressure (Figure 6).

393 Pairwise tests demonstrated significant differences in herbaceous beta-diversity

394 between unbrowsed and lightly browsed sites $(p<0.001)$, and between unbrowsed and

395 moderately-to-heavily browsed sites $(p<0.001)$. However, herbaceous communities did not

396 appear to differ significantly under light browsing and moderate-to-heavy browsing $(p=0.98)$.

397 Woody beta-diversity differed significantly between unbrowsed and moderately-to-heavily

398 browsed sites $(p=0.22$ ). However, beta-diversity did not differ significantly between lightly

399 browsed and unbrowsed sites $(p=0.55)$, or between lightly browsed and moderately-to-heavy

400 browsed sites $(p=0.16)$.

401 To determine how the abiotic and spatial covariates influenced these differences, we

402 performed a one-way permutational multivariate analysis of variance with grazing levels as a

403 factor, and controlling for covariates derived from the 'best' subset db-RDA models (Tables 2 and

404 3). For both herbaceous and woody communities, grazing intensity had a significant effect ( $p<$

4050.001 ) for herbaceous and woody species for 69 sites, and for herbaceous species for 78 sites, 
406 regardless of the order of entry in the model. However, grazing had a marginally significant on

407 beta-diversity in woody communities for 78 sites when it was entered last, confirming that was

408 spatially structured.

409

410

\section{Discussion}

411 Our results confirmed that the abiotic environment, grazing, and spatial relationships between

412 sites collectively shaped plant communities at Jebel Ichkeul, although their influence was strongest

413 in woody communities. However, the individual effect of grazing could not be disentangled from

414 the strong effect of space on overall plant beta-diversity in both the herbaceous and woody

415 communities, potentially reflecting the spatially autocorrelated nature of the grazing regime.

416 Grazing pressure and human activity incorporated using 0 . europaea sizes and densities as a

417 proxy, explained additional beta-diversity only in the woody community types, and had no

418 individual effects on the herbaceous community. Human activity thus appears to exert a slight

419 selective pressure in the woody community overall, though not in its herbaceous counterpart.

420 Although the overall effect of grazing on beta-diversity was highly confounded with space,

421 grazing intensities drove significant differences in beta-diversity in both the herbaceous and

422 woody communities. Moderate-to-heavy grazing appears to homogenize herbaceous

423 communities, and to a lesser extent, woody communities. Herbaceous communities in grazed

424 sites, regardless of intensity, differed from ungrazed sites. On the other hand, woody beta-

425 diversity differed only between unbrowsed and moderately-to-heavily browsed sites, suggesting

426 that woody communities were able to withstand light levels of browsing. Grazing's main effect

427 thus appeared to lie in shaping communities according to species' sensitivity to grazing, especially

428 at high intensity levels, although its overall effect on community composition was small. 
in Jebel Ichkeul, given that grazing's effect on community composition and species diversity is

431 scale-dependent and can be challenging to isolate (Brinkmann et al. 2009; Arevalo et al. 2011). As

432 space almost universally explained most of the variation in plant beta-diversity, some unmeasured

433 spatially-structured variables might be confounding the effect of grazing. It is also important to

434 note that this study was initially designed to sample floristically diverse communities and thus

435 intentionally neglected the denuded southern border of the mountain, rather than ensuring an

436 even sampling of different grazing regimes. Had we employed a grid sampling design stratified by

437 grazing, the overall effects of grazing on plant community composition might have been clearer.

438 Despite these sampling issues, we found that different levels of grazing intensity structure

439 compositionally dissimilar communities. Our results also suggested that herbaceous and woody

440 communities responded differently to grazing intensity. Herbaceous communities appeared to be

441 sensitive to both light and moderate to heavy grazing, and became homogenized under higher

442 grazing pressure. On the other hand, woody communities only differed from their unbrowsed

443 state in response to moderate to heavy grazing, suggesting that woody communities were robust

444 to intermediate grazing pressure (Gabay, Perevolotsky \& Shachak, 2006; Miguel-Ayanz, García-

445 Calvo \& Fernández-Olalla, 2010). This is consistent with a similar study in the Canary Islands,

446 where woody shrubs declined strongly from abandoned to heavily grazed areas (Fernández-Lugo

447 et al., 2013). Assuming that grazing intensity on woody species is representative of grazing

448 pressure on herbaceous species our findings suggest that management strategies should vary for

449 herbaceous and woody species under grazing regimes. However, we caution that our

450 interpretations could be confounded by differences in species diversity (144 herbaceous species, 
45135 woody species), by spatial autocorrelation in grazing pressure and beta-diversity within the two 452 community types.

453 Although the signal of grazing intensity's effect on plant community composition was

454 weak, this is likely due to limitations imposed by sampling design, categorical grazing pressure 455 measurements, and the assumption of equal grazing on herbaceous and woody communities 456 irrespective of livestock preferences. In fact, plant species on Jebel Ichkeul differed in their 457 responses to grazing, where some species are sensitive to increased grazing pressure, some are 458 maintained by moderate grazing pressure, and some are able to persist under even heavy grazing 459 pressure. This range of responses resulted in a heterogeneous cover of community types along the 460 mountain's grazing gradient. For example, some woody browse species (e.g., Ceratonia siliqua, 461 Coronilla valentina, Erica arborea, Erica multiflora and Rhamnus lycioides - Le Houérou 1981) are 462 sensitive to grazing, and were negatively correlated with the grazing gradient. Instead, the 463 increased humidity on the north side of the lake and deep valley soils allowed the development of

464 closed canopy forest dominated by Olea europea, Ceratonia siliqua and Phillyrea angustifolia. 465 Although these communities are species poor, they are of high ecological value because they are 466 representative of the Mediterranean basin's 'intact' vegetation, presenting an important 467 education and scientific opportunity for researchers and visitors to the national park. Elsewhere 468 in the Mediterranean, the Olea-Ceratonion formation is restricted to zones below $300 \mathrm{~m}$ 469 (Tomaselli, 1977).

470 Low matorral vegetation, comprised of species with the ability to persist under heavy 471 grazing pressure, was scattered on denuded xeric slopes along the mountain's heavily grazed 472 southeastern perimeter near gourbi villages on the southern face and the western end of the 
473 mountain. These highly grazed areas harboured herbaceous indicators of overgrazing, including

474 weedy species (Asteraceae) like Atractylis cancellata, Carthamus lanatus and Scolymus hispanicus,

475 and were lacking many sensitive woody browse species (e.g., Ceratonia siliqua, Coronilla

476 valentina, Erica arborea, and Rhamnus lycioides). Even Pistacia lentiscus, which is normally

477 resistant to grazing (Le Houerou, 1981), was sparse in these areas. These sensitive woody species

478 only occur on the southern slopes of the mountain when sheltered from grazing at higher

479 elevations below the ridge crest, outside the range of goatherds. This overgrazing creates

480 inhospitable conditions for establishment of other protective vegetation on the southern slopes of

481 the mountain, increasing insolation and aridity, and potentially exacerbating this problem.

482 While overgrazing erodes plant diversity, moderate grazing can maintain openings

483 between woody vegetation patches in some areas of Jebel Ichkeul, removing competing plant

484 biomass, providing nutrients from livestock manure, and ultimately increasing plant species

485 richness. For example, cattle $(45-60)$ and numerous wild boar that foraged in the Jebel Ichkeul

486 created the open conditions which suit Orchidaceae and Liliaceae (Fay, 1980), as well as various

487 socio-economically important pasture grass species (Noy-Meir \& Oron, 2001). Most of the orchid

488 species in the Ampelodesma stand at Saida Lalia Hadan, which contains the largest Olea europea in

489 the Park, are also maintained by intermediate levels of grazing (Fay 1980). Nevertheless,

490 Gramineae, which include some valuable pasture species, appeared to be excluded from heavily

491 grazed sites in Jebel Ichkeul. The level of grazing needed to maintain the richness of different plant

492 groups should thus be investigated in further research.

Importantly, more knowledge of the herbivore community might have shed more light on

494 the effects of grazing on plant community structure. An estimated 2,500 grazing animals on the 
495 mountain in 1980 (Fay, 1980; Anon, 1988), primarily comprised of goats in addition to sheep and

496 cattle (Hollis 1997). Livestock type affects grazing impacts on vegetation structure and composition

497 (Tóth et al., 2018), with goats generally being the most destructive species (Tomaselli, 1981).

498 Although the composition and abundance of the herbivore community were not assessed in this

499 study, their effect on the outcomes of grazing merit further investigation in future research.

$500 \quad$ Translating these findings into conservation and management recommendations requires

501 an acknowledgement of three major changes in human occupation and abiotic conditions at Jebel

502 Ichkeul since sampling occurred in 1983. First, around 1,000 people lived in the gourbi villages

503 along the southern flanks of the Jebel from 1983 to 2004, but this number dropped to 400 by

5042008 , declining until these villages were entirely evicted. Although grazing pressure has not been

505 completely eradicated, the change in livestock abundance and distribution is likely substantial.

506 Second, the limestone quarries which were contributing to xeric conditions through dust

507 deposition have been closed down (UNEP/WCMC, 2003). Third, Tunisia has undergone climate

508 change since at least the 1970s (Paeth et al., 2009), and faces a predicted $20 \%$ decrease in

509 precipitation and $1^{\circ}$ and $3^{\circ} \mathrm{C}$ increase in temperature by 2050 (Tramblay, El Adlouni \& Servat,

510 2013; Dakhlaoui et al., 2017). These changing climatic conditions, in addition to reduced dust

511 deposition and altered grazing regimes have probably substantially altered the relationships

512 investigated in this study. While the dams installed at all of the major rivers flowing into Lac

513 Ichkeul (UNEP/WCMC, 2003) could have created more xeric conditions, especially on the northern

514 slopes of the Jebel, this effect was likely temporary and minimal due to substantial rainfall

515 between 2003 and 2006, which restored former water and former salinity levels.

516

517 Conclusions and management recommendations 
518 Maintaining the heterogeneity and diversity of vegetation types and structure at Jebel Ichkeul is an

519 important management goal, in order to maintain the region's high ecological value (see Gabay et 520 al. 2006; Miguel-Ayanz et al. 2010). A key step towards this goal is the consistent monitoring of

521 the spatial distribution and structure of vegetation, particularly with regards to rare herbaceous

522 species and woody species. Importantly, our study provides a useful baseline of the plant

523 assemblages at Jebel Ichkeul with which to compare future vegetation changes. Re-surveying plant

524 assemblages at these survey sites could reveal how changes in grazing intensity, climate, and

525 human occupation have affected plant community composition and diversity over several

526 decades. Going forward, vegetation structure could be monitored using a combination of remote

527 sensing and on-the-ground metrics of patch size, patch density, or edge density (Glasser et al.

528 2013). However, ground truthing of species composition, gap dimensions and height of vegetation

529 would be essential, given that grazing pressure is focused below the canopy (Glasser et al. 2013),

530 though LiDAR imagery may circumvent this problem.

531 Recovering the maquis vegetation, particularly on the southern base of the mountain,

532 would protect the watershed by reducing soil erosion and consequent sedimentation of adjacent

533 marshland, and should therefore be a high priority goal. Restricting grazing and woodcutting on

534 the Jebel would directly facilitate this recovery. According to Fay (1980), the spatially

535 heterogeneous grazing pressure is the Jebel Ichkeul park's main conservation and management

536 problem. Managed grazing would be preferential to address this issue (Fernández-Lugo 2016;

537 Lázaro et al. 2016), rather than complete eradication of livestock, which can have unintended

538 consequences such as biological invasions or succession into less desirable communities (Mata et

539 al., 2014; Fernández-lugo, 2016). As such, implementing strategies to control grazing on the 
540 southern slopes of the mountain, combined with wood-cutting restrictions, could enable

541 vegetation to re-establish on the degraded southern slopes.

542 Effective management of the park should balance biodiversity goals with multiple uses,

543 including traditional pastoralism (Verdú, Crespo \& Galante, 2000; Perevolotsky, 2005), to maintain

544 valuable ecosystem services provided by the Jebel within Ichkeul national park (Daly-Hassen,

545 2017). A systematic conservation planning tool could prioritize areas based on maximizing

546 spatiotemporal variation in plant assemblages (Levin et al., 2013), effectively maintaining

547 vegetation diversity across the landscape, delineating zones for controlled grazing, and setting

548 biodiversity targets for specific vegetation types.

549 Given the predicted decreases in precipitation and increases in aridity (Tramblay, El

550 Adlouni \& Servat, 2013; Dakhlaoui et al., 2017) in North Africa, it is vital to consider the role of the

551 Jebel's complex topography and its proximity to Lake Ichkeul in creating microclimate refugia

552 (McLaughlin et al., 2017), which can locally buffer climate extremes for many endemic plant

553 species (Harrison \& Noss, 2017). The park's potential function as a climate refugium solidifies the

554 need to effectively manage grazing and other anthropogenic activities, in order to maintain plant

555 diversity and ecosystem functioning in this vulnerable region.

556

\section{Acknowledgements}

558 This research was conducted as part of a M.Sc. Thesis in Conservation at University College London

559 by the first author. Special thanks to J. M. Fay for pioneering this project (a plant inventory of

560 Jebel Ichkeul completed in 1980), and his devotion to protected area conservation in Africa. A.C.

561 Stevenson of UCL and R. Vickery of the British Museum (Natural History) helped with plant species 
562 identifications. We would also like to thank J. M. Fay, B. Green, the late G.E. Hollis, J.D. Skinner, A.

563 Warren and J.B. Wood for logistical support or advice. B.T. Collins helped with the equations for

564 olive diameter measurements. We are especially indebted to M. J. Anderson for statistical advice,

565 L. Olson for help with preliminary variance partititioning, C. Fauvelle for help with GIS, and A.

566 Daoud-Bouattour and M. Ouali for checking plant nomenclature. We thank A. Daoud-Bouattour,

567 R. G. Gavilan, P. W. Rundel and A. C. Stevenson for general comments on earlier drafts of this

568 manuscript. Two anonymous referees provided extremely helpful comments during formal review 569 of the manuscript.

570

571

572

573

574

575

576

577

578

579

580

581

582

583

\section{References}

Agra H, Ne'eman G. 2009. Woody species as landscape modulators: Their effect on the herbaceous plants in a Mediterranean maquis. Plant Ecology 205:165-177. DOI: 10.1007/s11258-009-9606-3.

Anderson MJ. 2006. Distance-based tests for homogeneity of multivariate dispersions. Biometrics 62:245-253. DOI: 10.1111/j.1541-0420.2005.00440.x.

Anderson MJ, Crist TO, Chase JM, Vellend M, Inouye BD, Freestone AL, Sanders NJ, Cornell H V., Comita LS, Davies KF, Harrison SP, Kraft NJB, Stegen JC, Swenson NG. 2011. Navigating the multiple meanings of $ß$ diversity: A roadmap for the practicing ecologist. Ecology Letters 14:19-28. DOI: 10.1111/j.1461-0248.2010.01552.x.

Anderson M, Gorley RN, Clarke KR. 2008. PERMANOVA + for PRIMER : by. Guide to Software and Statistical Methods 1.

Anon. 1988. Two Problematical National Parks in the Mediterranean Region. 
584 Arévalo JR, de Nascimento L, Fernández-Lugo S, Mata J, Bermejo L. 2011. Grazing effects on

585 species composition in different vegetation types (La Palma, Canary Islands). Acta

586 Oecologica 37:230-238. DOI: 10.1016/j.actao.2011.02.006.

587 Arevalo JR, De Nascimento L, Fernandez-Lugo S, Saro I, Camacho a., Mata J, Bermejo L. 2011.

588 Effects of abandoning long-term goat grazing on species composition and species richness

589 of pastures at La Gomera, Canary Islands. Spanish Journal of Agricultural Research 9:113-

590 123. DOI: $10.5424 /$ sjar/20110901-076-10.

591 Blondel, J., Aronson, J., Bodiou, J-Y and Boeuf G. 2010. The Mediterranean Region: Biological

592 Diversity in Space and Time. Oxford: Oxford University Press.

593 Borcard D, Legendre P, Drapeau P. 1992. Partialling out the Spatial Component of Ecological

$594 \quad$ Variation. Ecology 73:1045-1055.

595 Brinkmann K, Patzelt A, Dickhoefer U, Schlecht E, Buerkert A. 2009. Vegetation patterns and

596 diversity along an altitudinal and a grazing gradient in the Jabal al Akhdar mountain range

597 of northern Oman. Journal of Arid Environments 73:1035-1045. DOI:

$598 \quad$ 10.1016/j.jaridenv.2009.05.002.

599 Bunce RGH. 1982. A field key for classifying British woodland vegetation. Part 1. :103.

600 Campbell K, Donlan CJ. 2005. Feral goat eradications on islands. Conservation Biology 19:1362-

601 1374. DOI: 10.1111/j.1523-1739.2005.00228.x.

602 Di Castri F. 1981. Mediterranean-type shrublands of the world. In: Di Castri F, Goodall DW SR

603 ed. MediterraneanType Shrublands. Amsterdam, 1-52.

604 Chouhy D, Gil LB, Nocito AL, Wojdyla D, Ornella L, Cittadini J, Gardiol D, Giri AA. 2006.

605 Development and evaluation of a colorimetric PCR system for the detection and typing of 

human papillomaviruses. International Journal of Molecular Medicine 18:995-1003. DOI: 10.1016/j.ecolmodel.2006.02.015.

Cowling RM, Rundel PW, Lamont BB, Arroyo MK, Arianoutsou M. 1996. Plant diversity in mediterranean-climate regions. Trends in Ecology and Evolution 11:362-366. DOI:

Daget P. 1977. Le bioclimat mediterraneen: analyse des formes climatiques par le systeme d'emberger. Vegetatio 34:87-103.

Dakhlaoui H, Ruelland D, Tramblay Y, Bargaoui Z. 2017. Evaluating the robustness of conceptual rainfall-runoff models under climate variability in northern Tunisia. Journal of Hydrology 550:201-217. DOI: 10.1016/j.jhydrol.2017.04.032.

Daly-Hassen H. 2017. Valeur économique des services écosystémiques du Parc National de I'Ichkeul, Tunisie. Gland, Switzerland. Malaga, Spain.: IUCN.

618 Daoud-Bouattour, A., Gammar Ghrabi, Z., and Limam Ben Saad S. 2007. Guide illustré des 619 Plantes du Parc National de L'Ichkeul. Ariana Tunisie: Eco-Ressources International.

620 Dray, S., Bauman, D., Blanchet, G., Borcard, D., Clappe, S., Guenard, G., Jombart, T., Larocque, 621 G., Legendre, P., Madi, N., Wagner HH. 2018. Multivariate Multiscale Statistical Analysis: Package "Adespatial."

623 Elias D, Hölzel N, Tischew S. 2018. Goat paddock grazing improves the conservation status of 624 shrub-encroached dry grasslands. Tuexenia 38:215-233. DOI: 10.14471/2018.38.017.

625 Elias D, Tischew S. 2016. Goat pasturing-A biological solution to counteract shrub 626 encroachment on abandoned dry grasslands in Central Europe? Agriculture, Ecosystems 627 and Environment 234:98-106. DOI: 10.1016/j.agee.2016.02.023. 
628 European Environment Agency. 2017.G2.4 Olea europaea-Ceratonia siliqua woodland

629 Falcucci A, Maiorano L, Boitani L. 2007. Changes in land-use/land-cover patterns in Italy and 630 their implications for biodiversity conservation. Landscape Ecology 22:617-631. DOI:

$631 \quad$ 10.1007/s10980-006-9056-4.

632 Fay M. 1980. Flora of the National Park of Ichkeul, Tunisia.

633 Fernández-lugo S. 2016. Grazing management and impact in the Canary islands : Rethinking $634 \quad$ sustainable use.

635 Fernández-Lugo S, Arévalo JR, de Nascimento L, Mata J, Bermejo LA. 2013. Long-term

636 vegetation responses to different goat grazing regimes in semi-natural ecosystems: A case 637 study in Tenerife (Canary Islands). Applied Vegetation Science 16:74-83. DOI:

$638 \quad$ 10.1111/j.1654-109X.2012.01211.x.

639 Le Floc'h E, Boulos L, Vela E. 2010. Flore tunisie.

640 Gabay O, Perevolotsky a, Shachak M. 2006. Landscape mosaic for enhancing biodiversity : On

641 what scale and how to maintain it ? Options 49:45-49.

642 Geri F, Amici V, Rocchini D. 2010. Human activity impact on the heterogeneity of a

643 Mediterranean landscape. Applied Geography 30:370-379. DOI:

$644 \quad$ 10.1016/j.apgeog.2009.10.006.

645 Glasser, T., Hadar, L., Navon, Y., Perevolotsky A. 2013. Innovative monitoring of goat grazing

646 effects on landscape structural properties. DOI: 10.13140/2.1.2680.8003.

647 Gomez-Campo C. 1985. Plant Conservation in the Mediterranean. Dordrecht, The Netherlands:

$648 \quad$ W. Junk.

649 Harrison S, Noss R. 2017. Endemism hotspots are linked to stable climatic refugia. Annals of 
Botany 119:207-214. DOI: 10.1093/aob/mcw248.

651 Henkin Z. 2011. Cattle grazing and vegetation management for multiple use of Mediterranean shrubland in Israel. Israel Journal of Ecology \& Evolution 57:43-51. DOI: 10.1560/IJEE.57.1-

653 2.43.

Hill, J., Hostert, P., Tsiourlis, G., Kasapidis, P. \& Udelhoven T. 1998. Monitoring 20 years of intense grazing impact on the Greek island of Crete with earth observation satellites. Journal of Arid Environments 39:165-178.

Hollis GE. 1977. A Proposed Management Plan for the Internationally Important Parc National de L'Ichkeul, Tunisia. London.

Hollis GE. 1986. The Modelling and Management of the Internationally Important Wetland at Garaet El Ichkeul, Tunisia. I.

661 Le Houerou HN. 1981. Impact of man and his animals on Mediterranean vegetation. In: Di

662 Castri, F., Goodall, D.W. \& Specht RL ed. Ecosystems of the World Vol II: Mediterranean 663 type shrublands. London: Elsevier,.

664 Kirk DA. 1983. The plant associations of Djebel Ichkeul, northern Tunisia, in relation to site 665 factors and conservation implications. University College London.

667 The importance of functional diversity in the stability of Mediterranean shrubland 668 communities after the impact of extreme climatic events. Journal of Plant Ecology 669 10:rtw027. DOI: 10.1093/jpe/rtw027.

670 Lázaro A, Tscheulin T, Devalez J, Nakas G, Stefanaki A, Hanlidou E, Petanidou T. 2016.

671 Moderation is best: Effects of grazing intensity on plant-flower visitor networks in 

10.5061/dryad.p3c75.

674 Legendre, P., Legendre LFJ. 2012. Numerical Ecology. Elsevier.

675 Legendre P, De Cáceres M. 2013. Beta diversity as the variance of community data: Dissimilarity 676 coefficients and partitioning. Ecology Letters 16:951-963. DOI: 10.1111/ele.12141.

677 Legendre P, Gauthier O. 2014. Statistical methods for temporal and space-time analysis of 678 community composition data. Proceedings of the Royal Society B: Biological Sciences 281. $679 \quad$ DOI: $10.1098 /$ rspb.2013.2728.

680 Levin N, Watson JEM, Joseph LN, Grantham HS, Hadar L, Apel N, Perevolotsky A, DeMalach N, 681 Possingham HP, Kark S. 2013. A framework for systematic conservation planning and 682 683 10.1016/j.biocon.2012.08.032.

Mata J, de Nascimento L, Fernández-Lugo S, Arévalo JR, Viera JJ, Camacho A, Bermejo LA. 2014. 685 The inefficient planning of goat grazing: Causes and consequences. The Palmera breed 686 case (Canary Islands). Small Ruminant Research 121:125-130. DOI: 10.1016/j.smallrumres.2014.03.010.

Mazzoleni, S., G. di Pasquale, M. Mulligan, M. di Martino and FR. 2004. Recent dynamics of the 689 Mediterranean vegetation and landscape. West Sussex, England UK: Wiley. refugia, plants, and climate change. Global Change Biology 23:2941-2961. DOI:

692 10.1111/gcb.13629.

693 Médail, F. and Quézel P. 1997. Hot-spots analysis for conservation of plant biodiversity in the 
Mediterranean Basin. Annals of the Missouri Botanical Garden 84:112-127.

695 Miguel-Ayanz AS, García-Calvo RP, Fernández-Olalla M. 2010. Wild ungulates vs. Extensive 696 livestock. Looking back to face the future. Options Meditérraneennes 92:27-34.

697 Molina-Venegas R, Aparicio A, Lavergne S, Arroyo J. 2016. How soil and elevation shape local 698 plant biodiversity in a Mediterranean hotspot. Biodiversity and Conservation 25:11331149. DOI: 10.1007/s10531-016-1113-y.

Naveh Z. 1990. Fire in the Mediterranean - A Landscape Ecological Perspective. In: Goldammer,

701 J.F. JMJ ed. Fire in Ecosystems Dynamics. The Hague, Netherlands: SPB Academic $702 \quad$ Publishing,

703 Nogués-Bravo D, Araújo MB, Lasanta T, López-Moreno JI. 2008. Climate Change in 704 Mediterranean Mountains during the 21st Century. AMBIO: A Journal of the Human Environment 37:280-285. DOI: 10.1579/0044-7447(2008)37[280:CCIMMD]2.0.CO;2.

Nogués-Bravo D, López-Moreno Jl, Vicente-Serrano SM. 2012. Climate Change and its Impact. Mediterranean Mountain Environments:185-200. DOI: 10.1002/9781119941156.ch9.

Noy-Meir I, Oron T. 2001. Effects of grazing on geophytes in Mediterranean vegetation. Journal of Vegetation Science 12:749-760.

710 Olff H, Ritchie ME. 1998. Effects of herbivores on grassland plant diversity. Trends in Ecology and Evolution 13:261-265. DOI: 10.1016/S0169-5347(98)01364-0.

712 Olsvig-Whittaker L, Frankenberg E, Perevolotsky A, Ungar ED. 2006. Grazing, overgrazing and

713 conservation: Changing concepts and practices in the Negev rangelands. Science et 714 changements planétaires / Sécheresse 17:195-199.

715 Osem Y, Perevolotsky A, Kigel J. 2007. Interactive effects of grazing and shrubs on the annual 
716 plant community in semi-arid Mediterranean shrublands. Journal of Vegetation Science

717 18:869-+. DOI: 10.1111/j.1654-1103.2007.tb02603.x.

718 Paeth H, Born K, Girmes R, Podzun R, Jacob D. 2009. Regional climate change in tropical and

719 Northern Africa due to greenhouse forcing and land use changes. Journal of Climate

22:114-132. DOI: 10.1175/2008JCLI2390.1.

721 Papanastasis VP. 1998. Livestock grazing in Mediterranean ecosystems: an historical and policy

722 perspective. In: Papanastasis, V P and Peters D ed. ECOLOGICAL BASIS OF LIVESTOCK

723 GRAZING IN MEDITERRANEAN ECOSYSTEMS. Belgium: Proceedings of the International

724 Workshop held in Thessaloniki (Greece) on October 23-25, 1997, 5-9.

725 Papanastasis VP, Kyriakakis S, Kazakis G. 2002. Plant diversity in relation to overgrazing and

726 burning in mountain mediterranean ecosystems. Journal of Mediterranean Ecology 3:53-

72763.

728 Peres-Neto PR, Legendre P, Dray S, Borcard D. 2006. Variation Partitioning of Species Data

729 Matrices: Estimation and Comparison of Fractions. Ecology 87:2614-2625. DOI:

$730 \quad$ 10.1890/0012-9658(2006)87[2614:VPOSDM]2.0.CO;2.

731 Perevolotsky A. 2005. Livestock grazing and biodiversity conservation in Mediterranean

732 environments: the Israeli experience. Sustainable grazing, nutritional utilization and

733 quality of sheep and goat products 56:51-56.

734 Perevolotsky A, Seligman NG. 1998. Role of Grazing in Mediterranean Rangeland Ecosystems.

735 BioScience 48:1007-1017. DOI: 10.2307/1313457.

736 Peterken, G. L. and Radford GF. 1971. Report on field-trials in Tunisia. In: IBP/CT Progress

737 Report. 36-94. 
738 PlantBase E. 2017.The Euro+Med PlantBase - the information resource for Euro-Mediterranean

739 plant diversity. Available at http://www.emplantbase.org/home.html (accessed January 1, $740 \quad$ 2017).

741 Pons A. 1981. The history of Mediterranean shrublands. In: Di Castri F., Goodall, D. W. \& Specht

742 RL (Else ed. Mediterranean-Type Shrublands. Amsterdam: Elsevier, 131-138.

743 Quézel P. 1981. Floristic composition and phytosociological structure of sclerophyllous matorral

744 around the Mediterranean. In: Di Castri, F., Goodall, D.W. \& Specht RL ed. Ecosystems of

745 the World Vol II: Mediterranean type shrublands, . London: Elsevier, 107-121.

746 Rackham, O., Moody J. 1996. The Making of the Cretan Landscape. Manchester: Manchester

$747 \quad$ University Press.

748 Radford E., Catullo G, de Montmollin B. 2011. Important Plant Areas of the South and East

749 Mediterranean Region: Priority Sites for Conservation. DOI: 978-2-8317-1337-3.

750 Rundel PW. 1998. Landscape disturbance and biodiversity in Mediterranean-type ecosystems.

$751 \quad$ In: New York: Springer, 3-22.

752 Rundel PW, Arroyo MTK, Cowling RM, Keeley JE, Lamont BB, Vargas P. 2016. Mediterranean

753 Biomes: Evolution of their Vegetation, Floras and Climate. Annual Review of Ecology,

754 Evolution, and Systematics 47:383-407. DOI: 10.1146/annurev-ecolsys-121415-032330.

755 Rupprecht D, Gilhaus K, Hölzel N. 2016. Effects of year-round grazing on the vegetation of

756 nutrient-poor grass- and heathlands-Evidence from a large-scale survey. Agriculture,

757 Ecosystems and Environment 234:16-22. DOI: 10.1016/j.agee.2016.02.015.

758 Sardans J, Peñuelas J. 2013. Plant-soil interactions in Mediterranean forest and shrublands:

759 Impacts of climatic change. Plant and Soil 365:1-33. DOI: 10.1007/s11104-013-1591-6. 
760 Segoli M, Ungar ED, Giladi I, Arnon A, Shachak M. 2012. Untangling the positive and negative

761 effects of shrubs on herbaceous vegetation in drylands. Landscape Ecology 27:899-910.

$762 \quad$ DOI: $10.1007 / s 10980-012-9736-1$.

763 Sternberg M, Shoshany M. 2001. Influence of slope aspect on Mediterranean woody

764 formations: Comparison of a semiarid and an arid site in Israel. Ecological Research

765 16:335-345. DOI: 10.1046/j.1440-1703.2001.00393.x.

766

767

768

769

770

771

772

773

774

775

776

777

778

779

780

781

Tomaselli R. 1977. The degradation of the Mediterranean maquis. Ambio 6:356-362.

Tomaselli R. 1981. Main physionomic types and geographic distribution of shrub systems related to Mediterranean climates. In: Di Castri, F., Goodall, D.W. and Specht RL ed. Ecosystems of the World Vol II: Mediterranean type shrublands. London: Elsevier, 95-106.

Török P, Penksza K, Tóth E, Kelemen A, Sonkoly J, Tóthmérész B. 2018. Vegetation type and grazing intensity jointly shape grazing effects on grassland biodiversity. Ecology and Evolution 8:10326-10335. DOI: 10.1002/ece3.4508.

Török P, Valkó O, Deák B, Kelemen A, Tóth E, Tóthmérész B. 2016. Managing for species composition or diversity? Pastoral and free grazing systems in alkali steppes. Agriculture, Ecosystems and Environment 234:23-30. DOI: 10.1016/j.agee.2016.01.010.

Tóth E, Deák B, Valkó O, Kelemen A, Miglécz T, Tóthmérész B, Török P. 2018. Livestock Type is More Crucial Than Grazing Intensity: Traditional Cattle and Sheep Grazing in Short-Grass Steppes. Land Degradation and Development 29:231-239. DOI: 10.1002/ldr.2514.

Tramblay Y, El Adlouni S, Servat E. 2013. Trends and variability in extreme precipitation indices over maghreb countries. Natural Hazards and Earth System Sciences 13:3235-3248. DOI: 10.5194/nhess-13-3235-2013. 
782 Underwood EC, Viers JH, Klausmeyer KR, Cox RL, Shaw MR. 2009. Threats and biodiversity in

783 the mediterranean biome. Diversity and Distributions 15:188-197. DOI: 10.1111/j.1472-

$784 \quad$ 4642.2008.00518.x.

785 UNEP/WCMC. 2003. Ichkeul National Park. Management:1-10.

786 Verdú JR, Crespo MB, Galante E. 2000. Conservation strategy of a nature reserve in

787 Mediterranean ecossystems: the effect of protection from grazing on biodiversity.

$788 \quad$ Biodiversity \& Conservation 9:1707-1721.

789 Vogiatzakis IN, Mannion AM, Griffiths GH. 2006. Mediterranean ecosystems: problems and

790 tools for conservation. Progress in Physical Geography 30:175-200. DOI:

$791 \quad$ 10.1191/0309133306pp472ra.

792 Wilson KA, Underwood EC, Morrison SA, Klausmeyer KR, Murdoch WW, Reyers B, Wardell-

793 Johnson G, Marquet PA, Rundel PW, McBride MF, Pressey RL, Bode M, Hoekstra JM,

794 Andelman S, Looker M, Rondinini C, Kareiva P, Shaw MR, Possingham HP. 2007. Conserving

795 biodiversity efficiently: What to do, where, and when. PLoS Biology 5:1850-1861. DOI:

$796 \quad$ 10.1371/journal.pbio.0050223.

797 


\section{Table 1 (on next page)}

Biophysical variables measured at Jebel Ichkeul 


\begin{tabular}{llll}
\hline Variable & Mean \pm SE & Range & N \\
\hline Altitude m.a.s.I. & $143.0 \pm 12.7$ & $6-404$ & 78 \\
Aspect & & $20-360^{\circ}$ & 78 \\
Slope & $23.0 \pm 1.1$ & $4.3-64.5$ & 78 \\
Rock (\% cover) & $36.9 \pm 3.2$ & $0-90$ & 78 \\
pH & $7.36 \pm 0.03$ & $6.7-7.7$ & 50 \\
Density Olive A $(0-5 \mathrm{~cm})$ & & & \\
$30 \mathrm{~cm}$ & $1.48 \pm 0.45$ & $0-25$ & 69 \\
DBH & $2.03 \pm 0.63$ & $0-32$ & 69 \\
Density Olive B $(6-10 \mathrm{~cm})$ & & & 69 \\
$30 \mathrm{~cm}$ & $2.03 \pm 0.42$ & $0-15$ & 69 \\
DBH & $1.81 \pm 0.38$ & $0-15$ & 69 \\
Density Olive C $(11-15 \mathrm{~cm})$ & & & 69 \\
$30 \mathrm{~cm}$ & $1.41 \pm 0.24$ & $0-8$ & 69 \\
DBH & $1.20 \pm 0.21$ & $0-7$ & 69 \\
Density Olive D $(16-21 \mathrm{~cm})$ & & $0-4$ & \\
$30 \mathrm{~cm}$ & $0.74 \pm 0.18$ & $0-3$ & \\
DBH & $0.39 \pm 0.10$ & & \\
Density Olive E $(21 \mathrm{~cm}+)$ & & & \\
$30 \mathrm{~cm}$ & $0.41 \pm 0.11$ & & \\
DBH & & & \\
\hline
\end{tabular}




\section{Table 2 (on next page)}

Table 2. Permutational multivariate analysis of variance (Hellinger distance) testing herbaceous and woody species composition among grazing classes (crossed design, grazing as fixed effect) at 78 sites controlling for abiotic and spatial covariates.

a) Herbaceous; b) Woody. 
1

2 a) Herbaceous species

\begin{tabular}{|c|c|c|c|c|c|c|c|}
\hline & Source & Df & SS & MS & $\begin{array}{l}\text { Pseudo } \\
\text { F }\end{array}$ & $\begin{array}{l}P \\
\text { (perm) }\end{array}$ & $\begin{array}{l}\text { \# unique } \\
\text { permutations }\end{array}$ \\
\hline \multicolumn{8}{|l|}{ Grazing first } \\
\hline & Grazing & 2 & 2.6875 & 1.3437 & 1.995 & 0.0003 & 9830 \\
\hline & MEM1 & 1 & 1.5919 & 1.5919 & 2.363 & 0.0013 & 9880 \\
\hline & Residuals & 74 & 49.845 & 0.6736 & & & \\
\hline & Total & 77 & 54.12 & & & & \\
\hline \multicolumn{8}{|l|}{ Grazing last } \\
\hline & MEM1 & 1 & 1.5664 & 1.5664 & 2.326 & 0.0006 & 9858 \\
\hline & Grazing & 2 & 2.713 & 1.3565 & 2.014 & 0.0002 & 9839 \\
\hline & Residuals & 74 & 49.845 & 0.6735 & & & \\
\hline & Total & 77 & 54.124 & & & & \\
\hline
\end{tabular}


b) Woody species

6

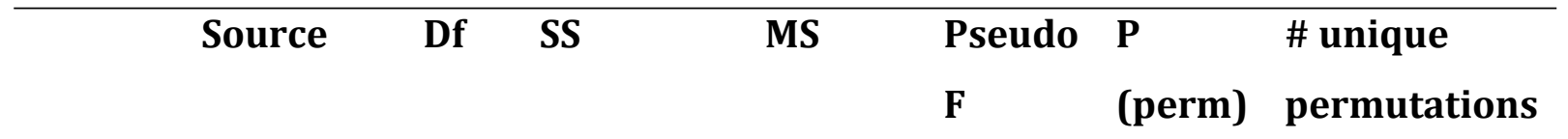

Grazing

first

$\begin{array}{lllllll}\text { Grazing } & 2 & 3.1109 & 1.5555 & 5.399 & 0.0001 & 9897 \\ \text { MEM1 } & 1 & 1.0529 & 1.0529 & 3.655 & 0.0004 & 9926 \\ \text { MEM2 } & 1 & 1.626 & 1.626 & 5.644 & 0.0001 & 9936 \\ \text { MEM3 } & 1 & 0.67419 & 0.67419 & 2.340 & 0.0127 & 9926 \\ \text { MEM4 } & 1 & 1.5297 & 1.5297 & 5.309 & 0.0001 & 9924 \\ \text { Residuals } & 71 & 21.456 & 0.28811 & & & \\ \text { Total } & 77 & 28.449 & & & & \end{array}$

Grazing

last

$\begin{array}{lllllll}\text { MEM1 } & 1 & 1.1044 & 1.1044 & 3.833 & 0.0004 & 9918 \\ \text { MEM2 } & 1 & 1.915 & 1.915 & 6.647 & 0.0001 & 9928 \\ \text { MEM3 } & 1 & 1.6641 & 1.6641 & 5.776 & 0.0001 & 9921 \\ \text { MEM4 } & 1 & 2.4528 & 2.4528 & 8.514 & 0.0001 & 9927 \\ \text { Grazing } & 2 & 0.85743 & 0.42871 & 1.488 & 0.0791 & 9902 \\ \text { Residuals } & 71 & 20.456 & 0.28811 & & & \\ \text { Total } & 77 & 28.449 & & & & \end{array}$

7

8 


\section{Table 3(on next page)}

Permutational multivariate ANOVA (Hellinger distance) testing herbaceous and woody species composition among grazing classes (crossed design, grazing as fixed effect) at 69 sites with Olea densities controlling for abiotic and spatial covariates.

a) Herbaceous; b) Woody. 
1

3 a) Herbaceous species

\begin{tabular}{|c|c|c|c|c|c|c|c|}
\hline & Source & Df & SS & MS & $\begin{array}{l}\text { Pseudo } \\
\text { F }\end{array}$ & $\begin{array}{l}P \\
\text { (perm) }\end{array}$ & $\begin{array}{l}\text { \# unique } \\
\text { permutations }\end{array}$ \\
\hline \multicolumn{8}{|l|}{ Grazing first } \\
\hline & Grazing & 2 & 2.1619 & 1.081 & 1.575 & 0.0055 & 9833 \\
\hline & MEM1 & 1 & 1.6556 & 1.6556 & 2.413 & 0.0004 & 9868 \\
\hline & Residuals & 65 & 44.603 & 0.6862 & & & \\
\hline & Total & 68 & 48.421 & & & & \\
\hline \multicolumn{8}{|l|}{ Grazing last } \\
\hline & MEM1 & 1 & 1.6396 & 1.6396 & 2.389 & 0.0003 & 9871 \\
\hline & Grazing & 2 & 2.178 & 1.089 & 1.587 & 0.0066 & 9827 \\
\hline & Residuals & 65 & 44.603 & 0.6862 & & & \\
\hline & Total & 68 & 48.421 & & & & \\
\hline
\end{tabular}


6

7

8

\begin{tabular}{|c|c|c|c|c|c|c|c|}
\hline & Source & Df & SS & MS & $\begin{array}{l}\text { Pseudo } \\
\text { F }\end{array}$ & $\begin{array}{l}P \\
\text { (perm) }\end{array}$ & $\begin{array}{l}\text { \# unique } \\
\text { permutations }\end{array}$ \\
\hline \multirow{2}{*}{\multicolumn{8}{|c|}{$\begin{array}{l}\text { Grazing } \\
\text { first }\end{array}$}} \\
\hline & & & & & & & \\
\hline & Grazing & 2 & 3.2019 & 1.6009 & 5.296 & 0.0001 & 9904 \\
\hline & MEM1 & 1 & 1.0699 & 1.0699 & 3.539 & 0.0004 & 9920 \\
\hline & MEM2 & 1 & 1.0382 & 1.0382 & 3.435 & 0.0007 & 9926 \\
\hline & MEM3 & 1 & 1.2522 & 1.2522 & 4.143 & 0.0002 & 9920 \\
\hline & MEM12 & 1 & 0.9975 & 0.9975 & 3.300 & 0.0007 & 9923 \\
\hline & Residuals & 62 & 18.741 & 0.30227 & & & \\
\hline & Total & 68 & 26.3 & & & & \\
\hline \multirow{2}{*}{\multicolumn{8}{|c|}{$\begin{array}{l}\text { Grazing } \\
\text { last }\end{array}$}} \\
\hline & & & & & & & \\
\hline & MEM1 & 1 & 1.1956 & 1.1956 & 3.955 & 0.0001 & 9924 \\
\hline & MEM2 & 1 & 1.3177 & 1.3177 & 4.359 & 0.0001 & 9918 \\
\hline & MEM3 & 1 & 2.2144 & 2.2144 & 7.326 & 0.0001 & 9914 \\
\hline & MEM12 & 1 & 1.4074 & 1.4074 & 4.656 & 0.0001 & 9934 \\
\hline & Grazing & 2 & 1.4246 & 0.71229 & 2.357 & 0.0010 & 9898 \\
\hline & Residuals & 62 & 18.741 & 0.30227 & & & \\
\hline & Total & 68 & 26.3 & & & & \\
\hline
\end{tabular}

b) Woody species 


\section{Figure 1}

Map of study sites on Jebel Ichkeul within Le Parc National de L'Ichkeul, and location within Tunisia (inset).

Points are coloured according to grazing class, where yellow $=$ unbrowsed, orange $=$ light browsing, and red = moderate-to-high browsing.

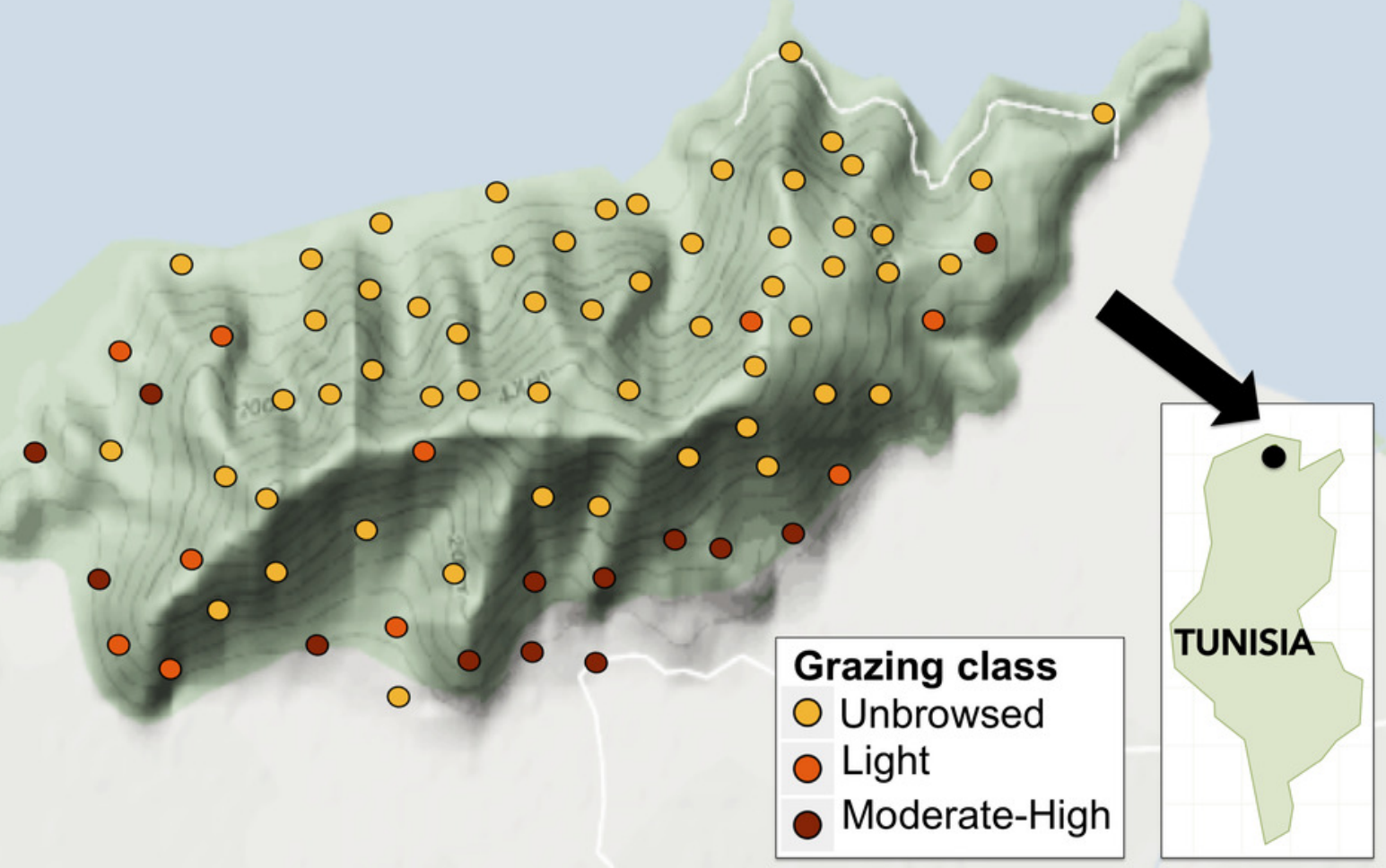


Figure 2

\section{A) Percent occurrence and B) relative abundance of woody plant species on Jebel Ichkeul within each of three grazing classes.}

Bars are coloured according to grazing class, where yellow $=$ unbrowsed, orange $=$ light browsing, and red = moderate-to-high browsing.
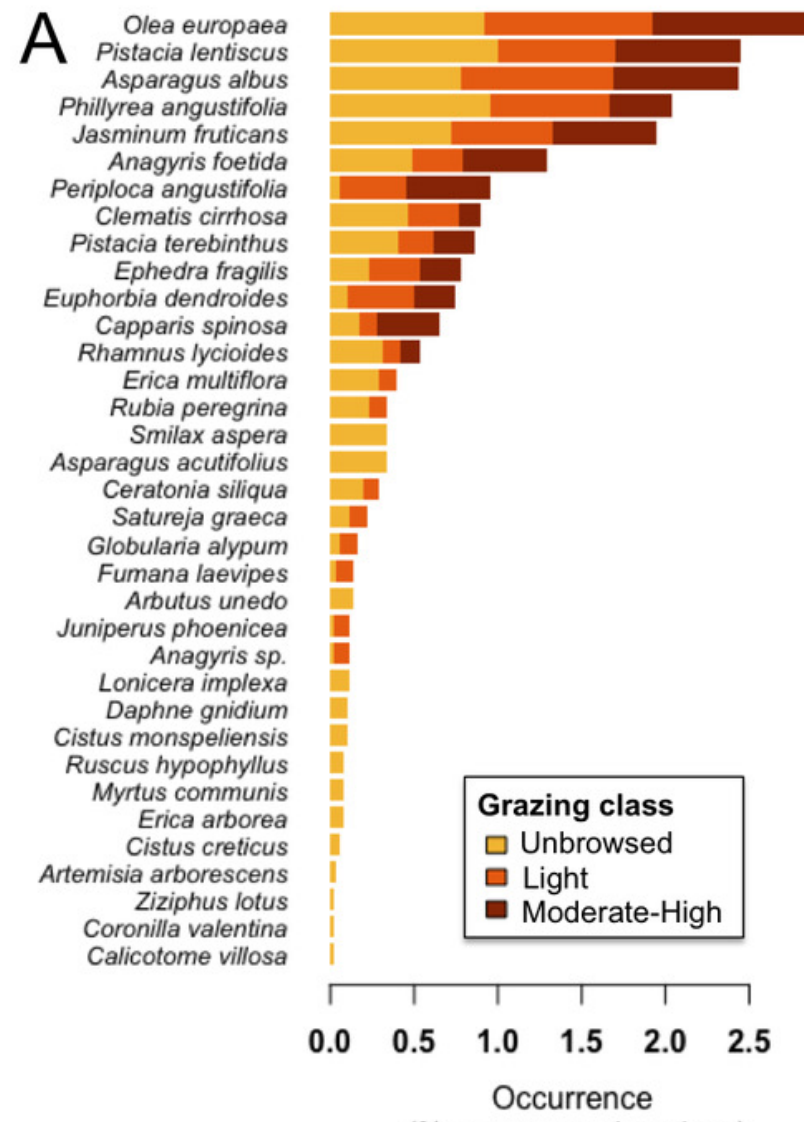

(\% across grazing class)

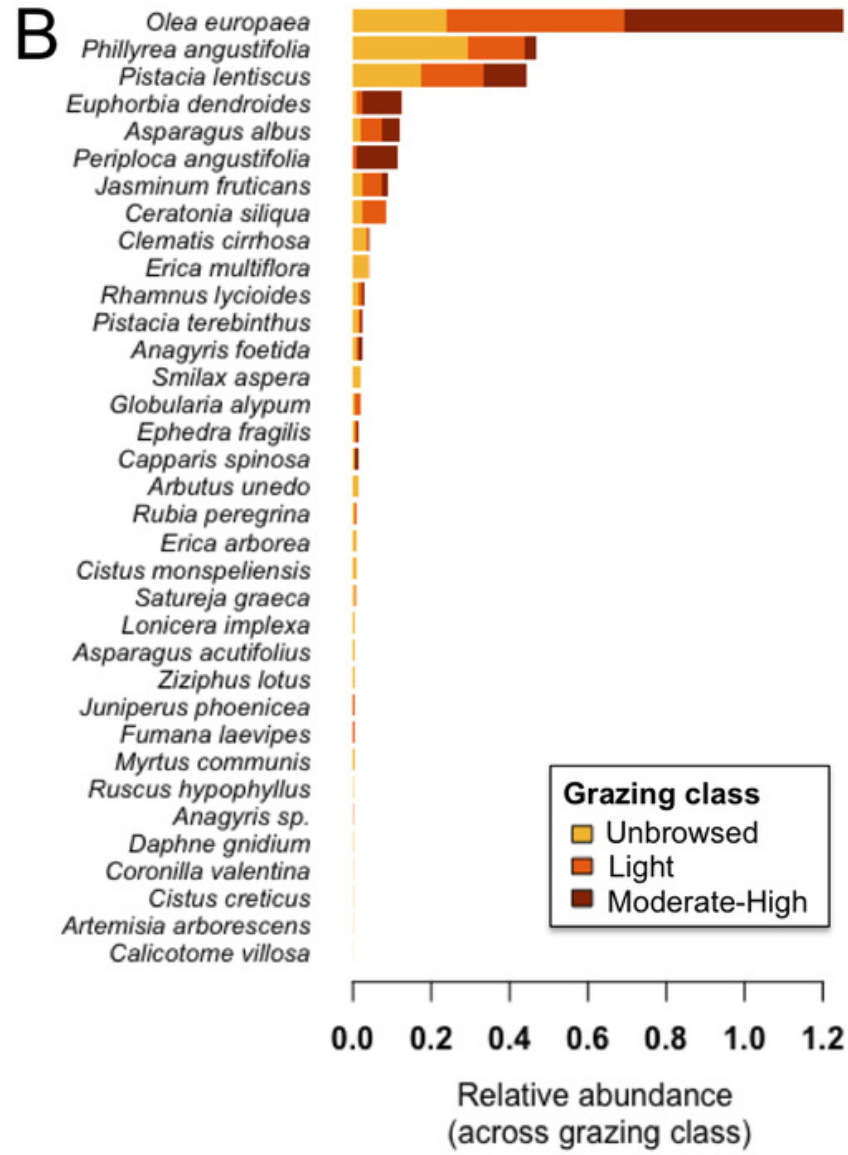


Figure 3

Local contributions to beta diversity of sites grouped by grazing class for a) herbaceous and b) woody plant communities on Jebel Ichkeul.

a) Herbaceous

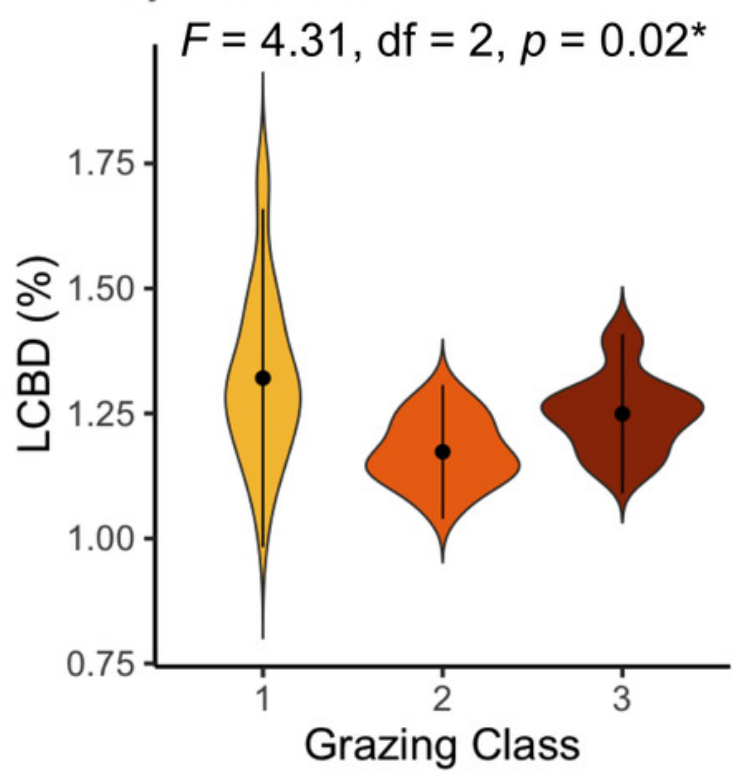

b) Woody

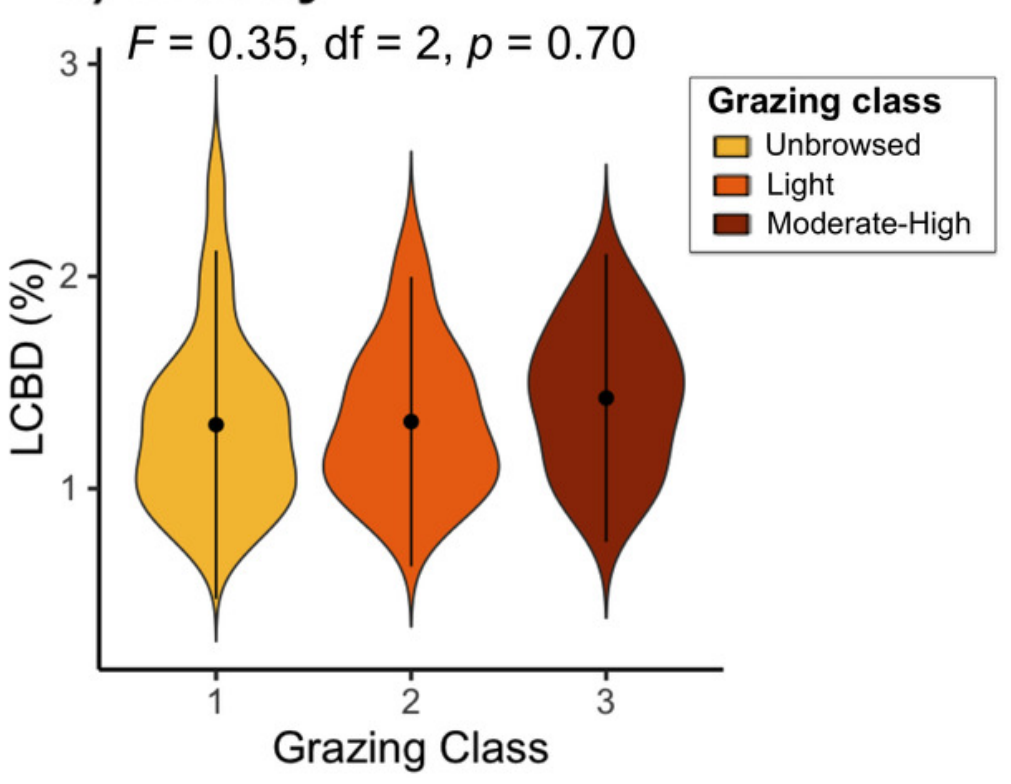


Figure 4

Species contributions to beta diversity (SCBD) of each functional group, in sites of each grazing class, for a) herbaceous and b) woody plant communities. 


\section{a) Herbaceous}
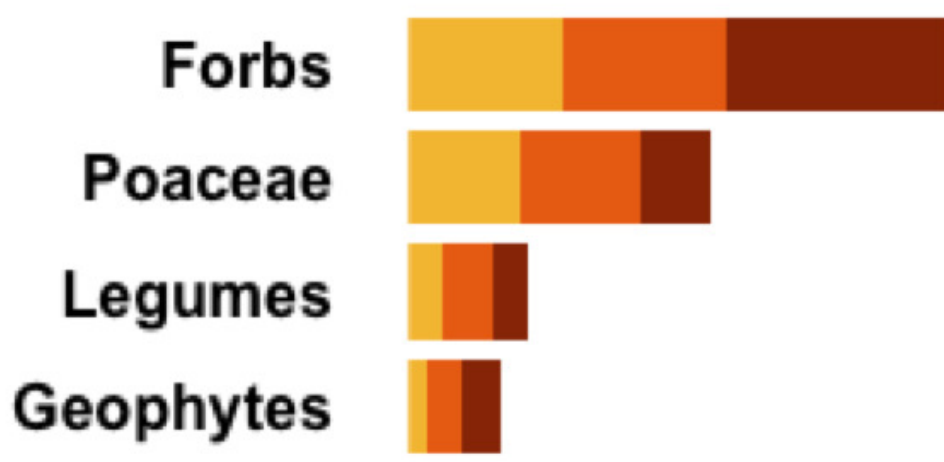

Grazing class

$\square$ Unbrowsed

$\square$ Light

$\square$ Moderate-High

\section{Geophytes}

\section{$\begin{array}{lllllll}0 & 50 & 100 & 150 & 200 & 250 & 300\end{array}$ SCBD (\%)}

\section{b) Woody}

\section{Other}

\section{Legumes}
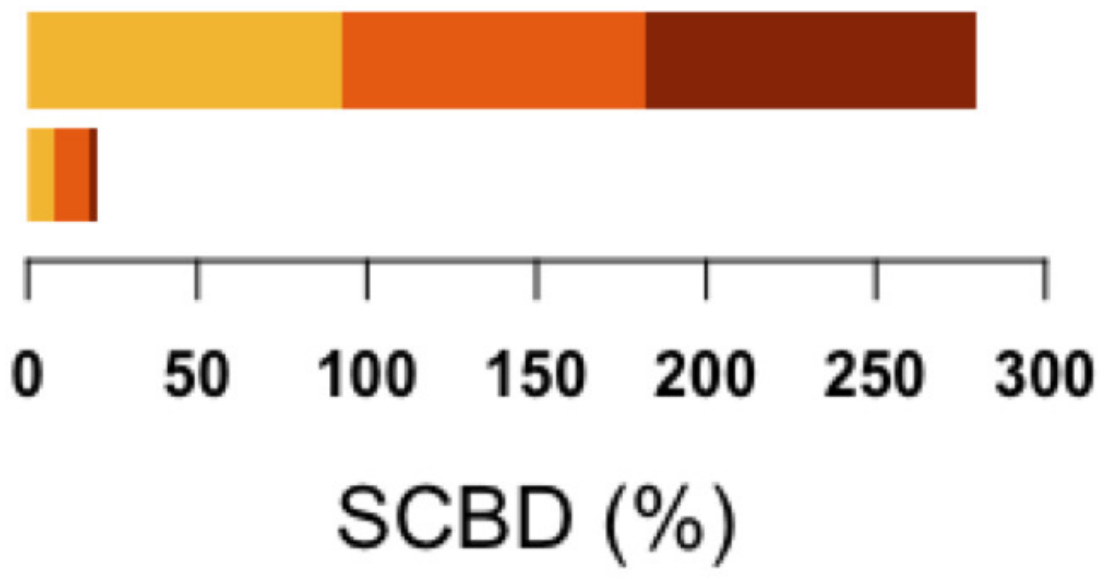


\section{Figure 5}

Variation partitioning of herbaceous $(a, c)$ and woody $(b, d)$ beta-diversity.

In a) and b): beta-diversity explained by abiotic, grazing, and spatial variables across 78 sites. In c) and d): beta-diversity explained by abiotic, grazing, 0 . europaea sizes and densities (as proxy for human activity), and spatial variables across 69 sites.
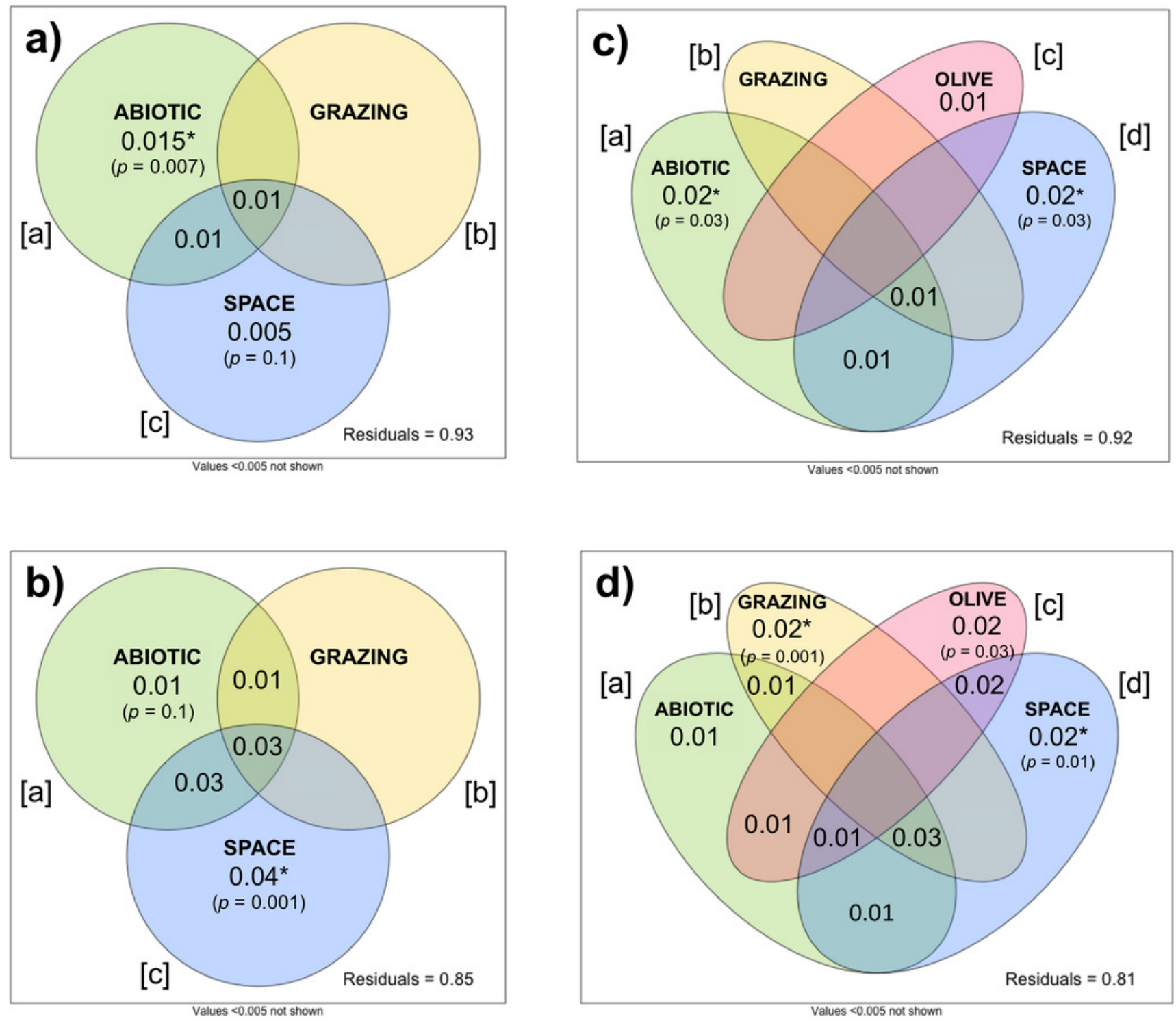
Figure 6

Test for homogeneity of multivariate dispersions between grazing classes for (a) herbaceous and (b) woody species.

a) Herbaceous

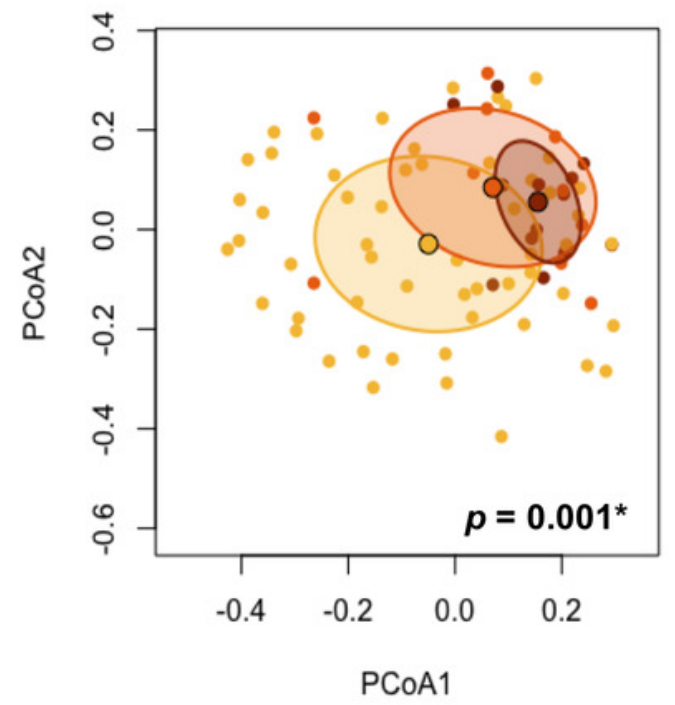

b) Woody

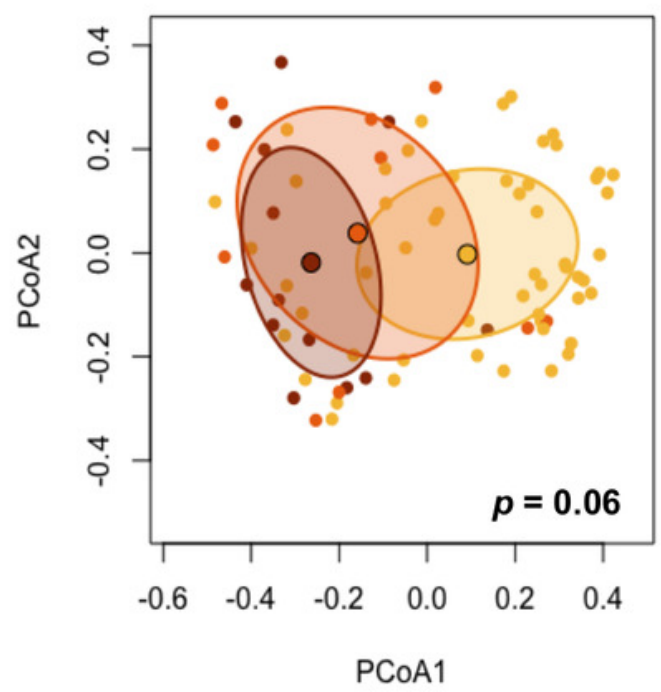

Grazing class $\square$ Unbrowsed $\square$ Light

- Moderate-High 